\title{
Analysis of Hospitalized Geriatric Patients from an Emergency Department
}

\section{Acil Servis Başvurusu Sonrası Hastaneye Yatırılan Yaşlı Hasta Grubunun Analizi}

\author{
DHarun Yıldırım', @Murtaza Kaya', @Eşref Genç², @Emine Kadıoğlu' \\ 'Kütahya Health Sciences University, School of Medicine Department of Emergency Medicine, Kutahya, Turkey \\ ${ }^{2}$ Kütahya Evliya Çelebi Training and Research Hospital, Department of Emergency Medicine, Kutahya, Turkey
}

\begin{abstract}
Objective: The increase in the geriatric population in industrialized countries also increases the rate at which this group utilizes emergency services. Evaluation of this patient group is not specific to a single discipline, but requires a multidisciplinary approach. Information obtained by examining emergency service use among geriatric patients can inform us of approaches to improve hospital efficiency and potentially reduce the morbidity and mortality rates.

Material and Method: This study investigated the retrospective records of geriatric patients who presented to emergency services during 2016 Kütahya Evliya Çelebi Training and Research Hospital, Turkey. Demographic characteristics, diagnoses, hospitalization rates, hospitalization according to clinics, seasonal characteristics, duration of hospital, and patient outcomes were evaluated. Study data were evaluated using the SPSS 20.00 statistical program.

Results: A total of 314.178 patients opted for emergency services during 2016, and 29.163 (9.2\%) were 65 years old and older. Among these patients, 10.545 were hospitalized, of whom 4.246 (40.2\%) were aged 65 years or older. The most frequently utilized hospital units were the cardiology $(n=723,17.02 \%)$, the neurology $(n=717$, $16.88 \%)$, and the chest diseases ( $n=674,15.87 \%)$.

Conclusion: The geriatric population requires that necessary changes should be made in healthcare structures. Our study, which evaluates hospitalization rates and health status in geriatric population at a provincial which can also provide a regional level, can help in making patient admission, follow-up, and rehabilitation more comprehensive.
\end{abstract}

Keywords: Geriatric assessment, emergency department, hospitalization

\section{Öz}

Amaç: Sanayileşmiş ülkelerde geriatrik yaş popülasyonunun artış göstermesi bu yaş grubu hastaların acil servislere başvuru oranını da arttırmaktadır. Ayrıca bu grubun değerlendirilmesi tek bir branşa özgü olmayıp multidisipliner bir yaklaşım gerektirmektedir. Dolayısıyla bu hasta grubunun acil servis başvurularının incelenmesiyle elde edilecek veriler müdahele zamanını kısaltabileceği gibi takiplerinde de hastane kaynaklarının verimli kullanımasını ve bunun sonucunda morbidite ve mortalite oranlarını azaltılması için yol gösterici olabilir.

Gereç ve Yöntem: Bu çalışma Kütahya Evliya Çelebi Eğitim Araştırma Hastanesi Acil Servisi'ne 01.01.2016 - 31.12.2016 tarihleri arasında başvuran geriatrik hastaların geriye dönük kayıtları incelenerek gerçekleştirilmiştir. İncelemede hastaların demografik özellikleri, tanıları, hastaneye yatış oranları, kliniklere göre dağılımı, mevsimsel özellikleri, hastanede yatış süreleri ve sonlanım durumları değerlendirilmeye alınmıştır. Çalışmada elde edilen veriler SPSS 20.00 programı kullanılarak değerlendirilmiştir

Bulgular: Çalışmanın yapıldığığı süre içerisinde acil servise yapılan başvuru sayısı 314.178 olup 29.163 'ü $(\% 9,2)$ atmışbeş yaş ve üzeri olduğu tesbit edildi. Bu dönem içerisinde acil servisten diğer servislere yatan hasta sayısı 10.545 olup, bunların 4246'sı $(\% 40,2) 65$ yaş ve üstü hasta grubunu oluşturdu. Yatış yapılan geriatrik hastaların klinik dağılımına bakıldığında en sık üç kilnik kardiyoloji ( $n=723, \% 17,02)$, nöroloji $(n=717, \% 16,88)$ ve göğüs hastalıkları $(n=674, \% 15,87)$ olarak tespit edildi.

Sonuç: Geriatrik hasta popülasyonunun hastaneye başvuru ve yatış oranlarının bölgesel olarak belirlenip değerlendirilmesi, ihtiyaca göre gerekli sağlık yapılanmasına yol göstererek, bu hastaların yatışı, takibi ve rehabilitasyonlarının daha nitelikli yapılmasına yol gösterebilir.

Anahtar Kelimeler: Geriatrik değerlendirme, acil servis, hastaneye yatış

Corresponding (illetişim): Emine KADIOĞLU, Kutahya Health Sciences University, School of Medicine Department of Emergency Medicine, Kutahya, Turkey

E-mail (E-posta): dreminekadioglu@gmail.com

Received (Geliş Tarihi): 21.04.2021 Accepted (Kabul Tarihi): 14.05.2021 


\section{INTRODUCTION}

Geriatric patients represent a special community for emergency services and although there is no clearly defined age range, many countries consider this cohort to begin from 65 years of age. ${ }^{[1]}$ Human life span is longer in industrialized countries. In the last 100 years, human life span has been extended by more than 25 years. Due to decreasing birth rates and improved medical care, the proportion of individuals aged over 80 years shows a particularly noticeable increase in the overall population. ${ }^{[2]}$ Life expectancy data from the World Health Organization shows that the estimated average lifespan in Turkey is 71 years for men and 75 years for women. ${ }^{[3]}$ According to the Turkish Statistical Institute, in 2014 , the geriatric population in Turkey was 6,192.962, i.e., $8 \%$ of the total population. The male population constitutes $43.6 \%$ and the female population constitutes $56.4 \%$ of the geriatric population. According to population projections, it is estimated that the geriatric population will increase to $10.2 \%$ of the total population by $2023,20.8 \%$ by 2050 , and $27.7 \%$ by $2075 .{ }^{[4]}$ Consistent with this increase, it has been estimated that rates of hospital presentation and emergency service utilization by geriatric population will grow when compared to those by the non-geriatric patient population. $[5,6]$

Physiological changes that occur with aging in the geriatric population result in a decrease in the functional capacity. These contribute to the emergence or exacerbation of many diseases, such as cardiovascular, nervous system, metabolic, and endocrine diseases. Chronic diseases present in older patients are exacerbated because of reduced physiological resources or electrolyte imbalances. ${ }^{[7,8]}$

It has been shown that at least $75 \%$ of the geriatric population is under drug treatment for one or more illnesses and that clinicians are more cautious when evaluating patients 9 . Emergency departments are specialized units that provide initial and timely evaluation of patients when they first arrive at the hospital. Physiological changes that occur among older individuals and the effects of existing chronic diseases and drug treatment regimens can prolong the evaluation process in emergency services. Accordingly, mortality and morbidity rates can be increased. Knowing these risks among geriatric patients, the emergency physician endeavors to make a prompt and accurate diagnosis, facilitate appropriate treatment, and use existing facilities efficiently as part of a multidisciplinary care team.

The hospital where the present research was undertaken is the only public hospital in the center of the Kutahya city in Aegean Region of Turkey. It provides 750 medical and care beds and 90 intensive care beds. This study evaluates the rates of hospitalization of geriatric patients in the rural hospital in Aegean Region of Turkey in order to inform more efficient use of hospital resources, diagnostic and treatment services, and follow-up and rehabilitation according to patients' level of need.

\section{MATERIAL AND METHOD}

This study was undertaken to investigate the retrospective records of geriatric patients who presented to emergency services at Kütahya Evliya Çelebi Training and Research Hospital between 01.01.2016 and 31.12.2016. The medical records of our patients were accessed via the hospital's data automation system. The study protocol conformed to the ethical guidelines of the Declaration of Helsinki and was reviewed and approved by the Clinical Research Ethics Committee of Dumlupınar Universty (Permission granted: 18.01.2017, Decision no:2017/06 2018/8-1).

\section{Statistical Analysis}

The study population consisted of geriatric patients (>65 years old). The demographic characteristics of patients, hospitalization rates, hospitalization according to clinics, seasonal characteristics, and length of stay and outcomes of patient hospitalization were evaluated using SPSS (Version 20.0, SPSS Inc., Chicago, IL). Descriptive statistics (mean \pm SD) and percentage were calculated for all variables.

\section{RESULTS}

A total of 314.178 patients were enrolled in the study during 2016 , and 29.163 (9.2\%) of these patients were aged 65 years and more. The number of patients hospitalized to emergency services during the study was 10,546. Among this group, $4.246(40.2 \%)$ patients were aged over 65 years. The sample of 4.246 patients over 65 years had a mean age of $76.1 \pm 7.0$ (range, 65-102). The study sample comprised 2.027 (47.7\%) females and 2.219 (52.3\%) males (Table 1). The average age of female patients was $76.8 \pm 7.1$, while that of male patients was $75.4 \pm 6.8$.When the referral complaints of patients admitted to the clinics were evaluated, the three most common symptoms were dyspnea, chest pain, and general impairment. The most common diagnoses were respiratory system disorders, cardiac disorders and neurological diseases. Patients were admitted to the appropriate clinics following a review of their symptoms and examinations performed at the end of the study. Accordingly, 3.352 (78.9\%) patients were admitted to internal clinics, and 894 (21\%) patients were admitted to surgical clinics.

The most common symptoms were chest pain, general impairment, and shortness of breath when considering presentations to the emergency unit of internal clinics. Most common patient diagnoses included respiratory system disorders, cardiac disorders and neurological diseases. Commonly attended internal medicine clinics included cardiology, neurology, chest diseases, and internal diseases in the order of frequency. Patients hospitalized to the emergency unit of surgical clinics were found to most commonly have abdominal pain, trauma, and chest pain. The most common diagnoses of these patients were acute abdominal problems, trauma-related fractures, and cardiac diseases among patients who were awaiting a surgery. The most common 
of hospitalized clinics were general surgery, orthopedics, traumatology, cardiovascular surgery, and neurosurgery according to frequency of the patients who were admitted to surgical clinics. When the service and intensive care rates of patients were examined, 2.640 (62.2\%) were hospitalized and 1.606 patients (37.8\%) were admitted to intensive care. The average duration of hospitalization was 9.9 days in intensive care and 12.1 days in other services. When seasonal rates of patient admissions were examined, geriatric patients visited the chest diseases unit and intensive care unit commonly during spring $(n=203)$ and winter $(n=259)$, and the internal disease unit common during autumn $(n=185)$. Patient admission to the cardiology unit and coronary intensive care unit also increased during autumn (Table 1). When the outcomes of the patients were examined, 714 patients (16.9\%) were discharged due to life termination, 41 patients (1\%) were referred for further examination and treatment, and 3.491 patients (82.1\%) were discharged (Table 2).

\section{DISCUSSION}

With aging, functional capacity decreases and chronic disease prevalence increases. This often leads to the emergence of acute diseases, either independently or in association with existing illness. ${ }^{[10]} \mathrm{A}$ multidisciplinary approach is needed to determine the etiologic basis of acute or chronic diseases that are encountered in emergency services..$^{[10,11]}$ Multidisciplinary teams are necessary as it takes time and diverse skills to complete the necessary examinations and consultations. ${ }^{[11-13]}$

In studies of geriatric patients, the rates of admission to emergency services have been shown to vary considerably from $11.5 \%$ to $50 \% \cdot{ }^{[11-14]}$ In our study, the rate of admission was $9.2 \%$. This rate appears to be affected by the characteristics of the geographical region and the local population. In the Agean Part of Turkey, the sampling frame for the current study, $11 \%$ of the provincial population constitutes the age group defined as geriatric, as determined in 2013. ${ }^{[4]}$ Therefore,

Table 1. Distribution of the patients according to diagnoses, Demographic features and Seasonal distiribution

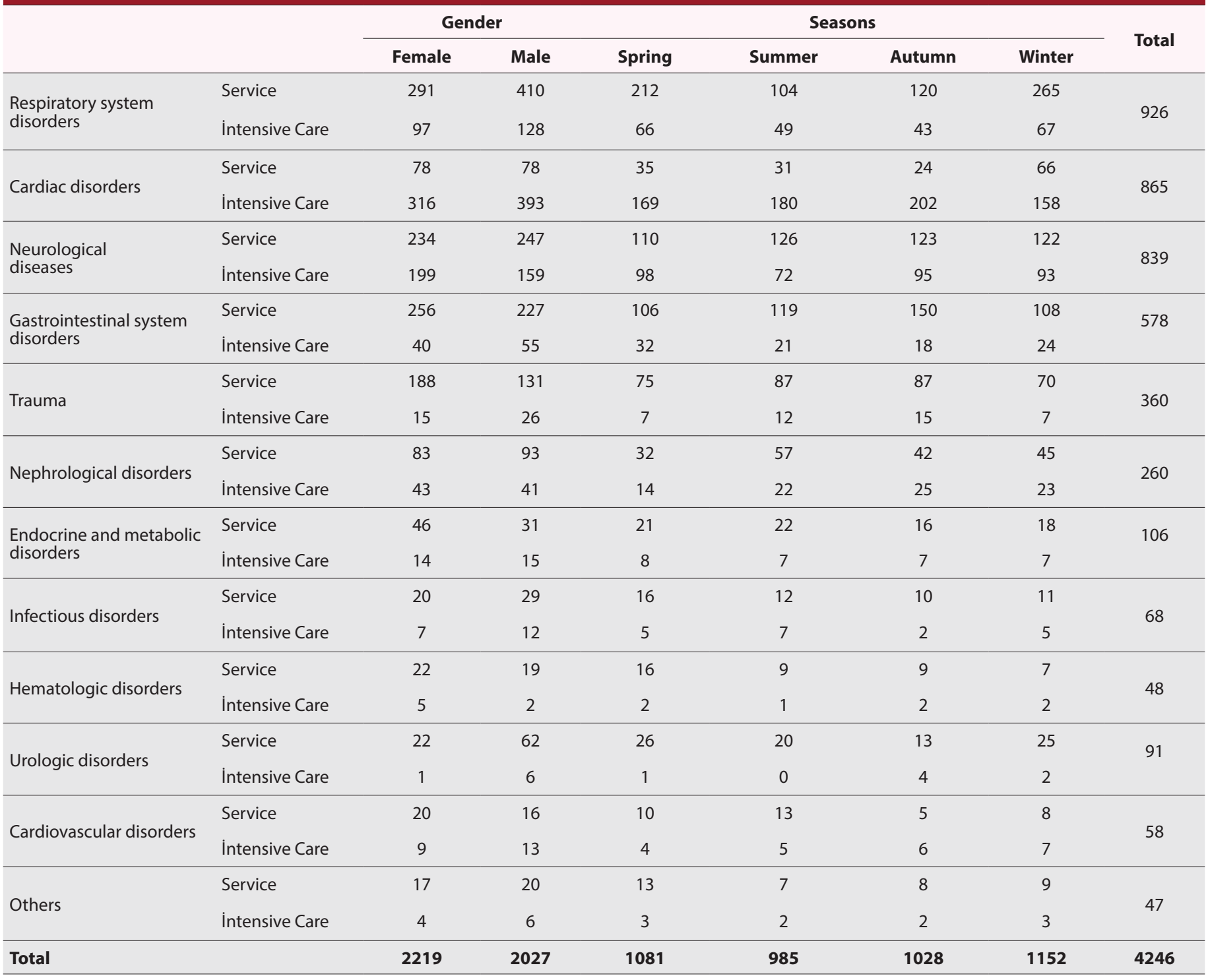


Table 2. Distribution of the patients according to diagnoses and outcome of patients

\begin{tabular}{|c|c|c|c|c|c|c|}
\hline \multirow{2}{*}{ Diagnosis } & & \multicolumn{4}{|c|}{ Outcome of patients } & \multirow{2}{*}{ Tota } \\
\hline & & Discharged & Exitus & Transport & Refuse & \\
\hline \multirow{2}{*}{ Respiratory system disorders } & Service & 607 & 78 & 3 & 13 & 701 \\
\hline & İntensive Care & 116 & 100 & 4 & 5 & 225 \\
\hline \multirow{2}{*}{ Cardiac disorders } & Service & 141 & 14 & 1 & 0 & 156 \\
\hline & İntensive Care & 581 & 103 & 8 & 17 & 709 \\
\hline \multirow{2}{*}{ Gastrointestinal system disorders } & Service & 413 & 52 & 15 & 3 & 483 \\
\hline & İntensive Care & 57 & 35 & 2 & 1 & 95 \\
\hline \multirow{2}{*}{ Neurological diseases } & Service & 436 & 39 & 5 & 1 & 481 \\
\hline & İntensive Care & 227 & 126 & 2 & 3 & 358 \\
\hline \multirow{2}{*}{ Trauma } & Service & 289 & 22 & 7 & 1 & 319 \\
\hline & İntensive Care & 26 & 14 & 1 & 0 & 41 \\
\hline \multirow{2}{*}{ Nephrological disorders } & Service & 150 & 24 & 0 & 2 & 176 \\
\hline & Intensive Care & 39 & 44 & 0 & 1 & 84 \\
\hline \multirow{2}{*}{ Endocrine and metabolic disorders } & Service & 71 & 6 & 0 & 0 & 77 \\
\hline & Intensive Care & 17 & 12 & 0 & 0 & 29 \\
\hline \multirow{2}{*}{ Infectious disorders } & Service & 37 & 12 & 0 & 0 & 49 \\
\hline & Intensive Care & 8 & 10 & 1 & 0 & 19 \\
\hline \multirow{2}{*}{ Hematologic disorders } & Service & 36 & 4 & 1 & 0 & 41 \\
\hline & Intensive Care & 5 & 2 & 0 & 0 & 7 \\
\hline \multirow[t]{2}{*}{ Urologic disorders } & Service & 76 & 5 & 0 & 3 & 84 \\
\hline & Intensive Care & 7 & 0 & 0 & 0 & 7 \\
\hline \multirow{2}{*}{ Cardiovascular disorders } & Service & 31 & 2 & 1 & 2 & 36 \\
\hline & Intensive Care & 17 & 5 & 0 & 0 & 22 \\
\hline \multirow{2}{*}{ Other } & Service & 32 & 4 & 1 & 0 & 37 \\
\hline & Intensive Care & 8 & 1 & 0 & 1 & 10 \\
\hline Total & & 3427 & 714 & 52 & 53 & 4246 \\
\hline
\end{tabular}

the geriatric population admitted to hospital was found to be in proportion to the overall population. One noteworthy element of this study is that it provides evidence for the current patient population in the provincial center because Kütahya Evliya Çelebi Training and Research Hospital can present large scale of population due to its location.

Several studies regarding the utilization of emergency hospital services by geriatric patients have been undertaken internationally. In a study conducted by Kekeç et al. ${ }^{[15]}$ the three most common causes of admission were metabolic or systemic diseases, cardiovasculardiseases, and cerebrovasculardiseases. In another study, Ünsal et al. ${ }^{[10]}$ assessed the emergency service presentations of older patients and determined that the most frequent causes of admission were hypertension, cardiac and pulmonary diseases, and upper respiratory tract and urinary tract infections. In a study performed by Castella et al. ${ }^{[16]}$ it was reported that cardiovascular diseases were the main cause of admission to hospitals in older patients across the both sexes. In our study, the three most common causes of admission were chronic pulmonary diseases, cardiovascular diseases, and cerebrovascular diseases. In addition to cardiovascular and respiratory system diseases, studies have reported fallrelated injuries among older adults as frequent causes of admission. ${ }^{[17,18]}$ In our study, trauma was ranked seventh in general prevalence among the referrals of older patients and second in surgical cases.
In the literature, emergency hospitalization rates among the geriatric age group range from $11.5 \%$ to $61 \% .{ }^{[14,15]}$ Vanpee et al. ${ }^{[11]}$ reported a $69 \%$ hospital admission rate in their study of a patient population over 75 years of age. The wide range of hospital admission rates among older adults is explained by the fact that countries have different definitions of geriatric population. ${ }^{[11]}$ In our study, the hospitalization rate of the geriatric patient population increased in proportion with the other age groups (40.2\%), which is consistent with the literature. When the patient group that was admitted to the emergency department was evaluated, it was determined that one out of every three patients was in the geriatric age group.

Two ways in which our findings differ from the international literature relate to length of hospital stay and outcomes of geriatric age group hospitalization. The average duration of hospitalization was 12.1 days for intensive care and 9.9 days for other services among the geriatric group of patients.

When presentations of the geriatric age group were evaluated in relation to emergency department admissions, reasons for illness included the presence of co-existing diseases accompanying the presenting condition, deterioration of cognitive function, and slowness of movement. ${ }^{[2,19]}$ In addition to these reasons, all necessary tests for geriatric patient diagnoses and determination of appropriate treatments could not always be made. Barriers to diagnosis and treatment 
included the lack of adequate equipmentand the inappropriate physical conditions of the emergency room. For this reason, the recommended service model for older patients is the geriatric emergency service, where appropriate equipment, physical environment, and well-trained multidisciplinary staff are available. ${ }^{[20]}$

Comprehensive assessment to guide diagnosis is important for geriatric care. In their evaluation of the efficacy of geriatric assessment in emergency services, Garf et al. ${ }^{[21]}$ concluded that comprehensive geriatric assessment reduced the requirement of functional assistance, re-admission to hospital, and needs for long-term care. However, rapid circulation in the emergency department prevents comprehensive geriatric assessment. For this reason, different methods have been suggested in the literature to admit older patients to emergency services. ${ }^{[21-25]}$ In recent times, hospitals have begun to restructure their physical environments for older patients, and some have set up geriatric monitoring departments with bed capacities of four to seven. ${ }^{[20]}$

\section{CONCLUSION}

In these conditions, we believe that geriatric age group admission rates and health status can lead to the establishment of regional geriatric care centers, even if they are not provincial, so that the admission, follow-up, and rehabilitation of these patients can be more comprehensive.

\section{ETHICAL DECLARATIONS}

Ethics Committee Approval: The study protocol was approved by the Medical Ethics Committee of Dumlupınar Universty (Permission granted: 18.01.2017, Decision no:2017/06 2018/8-1).

Informed Consent: Because the study was designed retrospectively, no written informed consent form was obtained from patients.

Referee Evaluation Process: Externally peer-reviewed.

Conflict of Interest Statement: The author(s) declared no potential conflicts of interest with respect to the research, authorship, and/or publication of this article.

Financial Disclosure: The authors declared that this study has received no financial support.

Author Contributions: All of the authors declare that they have all participated in the design, execution, and analysis of the paper, and that they have approved the final version.

\section{REFERENCES}

1. www.turkgeriatrivakfi.org.tr [updated 22 Agust 2020]

2. Yaman H. The Effect of Sports to The Physiological Function In The Elderly, Turk J Geriatr 2003;6 (4):142-6.

3. World Health Organization. Erişim: http://www.int/country/tur/en. [updated 22 Agust 2020]

4. www.tüik.gov.tr [updated 22 Agust 2020]
5. Unsal A, Ayranci U, Cevik A, et al. Use of Emergency Departments by Elderly Patients in a City of Western Turkey. Eur J Emerg Med 2007;14:1259.

6. Strange GR. Use of Emergency Departments by elder patients:a five year follow up study. Acad. Emerg Med 1998;5:115.

7. Aslan Ş, Atalay A, Kutsal Y. Drug Use In Elderly. Turk J Geriatr 2000;3:56-60.

8. Kutsal Y. Polypharmacy In Elderly. Turk J Geriatr 2006;37-44.

9. Berberoğlu U, Gül H, Eskiocak $M$, et al. Some Socio-Demographic Specialities And Daily Activities Of The Elderly People According To The Katz Index Who Live In Edirne Rest House. Turk J Geriatr 2002;5:144-9.

10. Unsal A, Çevik AA, Metintaşı S, et al. Emergency Department visits by Elder Patients. Turk J Geriatr 2003;6:83-8.

11. Vanpee D, Swine C, Vandenbossche P, Gillet JB. Epidemiological profile of geriatric patients admitted to the emergency department of a university hospital localized in a rural area. Eur J Emerg Med 2001;8:301-4.

12. Hu SC, Yen D, Yu YC, et al. Elderly use of the ED in an Asian metropolis. Am J Emerg Med 1999;17:95-9.

13. McLigeyo SO. The pattern of geriatric admissions in the medical wards at the Kenyatta National Hospital. East Afr Med J 1993;70:37-9.

14. Mert E. Use of emergency departments by elderly patients. Turk J Geriatr 2006;9:70-4.

15. Kekeç Z, Koç F, Büyük S. Review of geriatric patients hospitalization in emergency department. J Acad Emerg Med 2009;8:21-4.

16. Castella X, Mompart A, Perez G. [Hospital utilization for acute problems of the elderly. Catalonia, 1982-1990]. Gac Sanit 1997;1:259-65.

17. Lim KH, Yap KB .The presentation of elderly people at an emergency department in Singapore. Singapore Med J 1999;40:742-4.

18. Hamdy RC, Forrest LJ, Moore SW, Cancellaro L. Use of emergency departments by the elderly in rural areas. South Med J 1997;90:616-20.

19. Singal BM, Hedges JR, Rousseau EW, et al. Geriatric patient emergency visits part I:comparison of visits by geriatric and younger patients. Ann Emerg Med 1992;21:802-7.

20. Hwang U, Morrison RS. The geriatric emergency department, model of geriatric care, quality improvement, and program dissemination. J Am Geriatr Soc 2007;55:1873-6.

21. Graf CE, Zekry D, Giannelli S, et al. Comprenhensive geriatric assessment in the emergency department. JAGC 2010;58:2032-3.

22. McCusker J, Dendukuri N, Tousignant $P$, et al. Rapid two stage emergency department intervention for senior:impact on continuty of care. Acad Emerg Med 2003;10:233-43.

23. Meldon SW, Mion LC, Palmer RM, et al. A Brief risk-stratification tool to predict repeat emergency department visits and hospitalizations in older patients discharged from the emergency department. Acad Emerg Med 2003; 10:224-32.

24. McCusker J, Bellavance R, Cardin S, et al. Detection of older people at increased risk of adverse health outcomes after an emergency visit:the ISAR screening tool. J Am Geriatr Soc 1999;47:1229-37.

25. Scharf AC, Gronewold J, Dahlmann C, et al. Health outcome of older hospitalized patients in internal medicine environments evaluated by Identification of Seniors at Risk (ISAR) screening and geriatric assessment. BMC Geriatr 2019;221. 